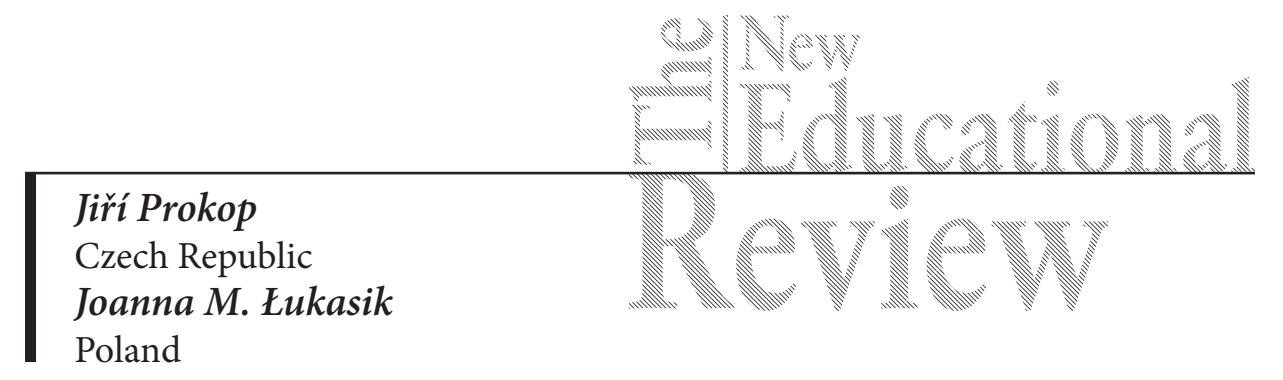

\title{
Everyday Professional Life Experiences of Teachers in the Midlife Transition Period
}

DOI: 10.15804/tner.2015.41.3.17

\begin{abstract}
The article presents the meaning of professional work as experienced by teachers in the midlife transition period (the concept by P. Oleś). Qualitative research conducted with the use of an autobiographical method (a reference to the journal writing tradition of F. Znaniecki and his followers, including pedeutology experts) has been placed within the framework of everyday life sociology as presented by A. Schütz, P. Berger and T. Luckmann, and P. Sztompka. The purpose of the presented study is to focus on how the stage of one's development influences the quality of work and determines the meaning and importance of professional experiences. In order to describe it, a reference has been made to the research conducted among 6 female teachers in the midlife transition period.
\end{abstract}

Keywords: teacher, work, everyday life, autobiography, midlife transition period

\section{Introduction}

In sociology, the concept of everyday life has been in use since the early 1930s thanks to the theory of everyday life offered by Alfred Schütz (1962). A theoretical basis for understanding everyday life - adopted for the purpose of this analysis - was also discussed by P. Berger and T. Luckmann. These researchers perceived everyday life as the paramount reality, claiming that: "The tension of consciousness is highest in everyday life, that is, the latter imposes itself upon consciousness in the most massive, urgent and intense manner. It is impossible to ignore, difficult to weaken its imperative presence. Consequently, it forces me to be attentive to it 
in the fullest way" (Berger, Luckmann, 1966, p. 37). In P. Berger and T. Luckmann's view, everyday life has its temporal and spatial structure. Furthermore, it is "an ordered reality". This follows from the fact that its phenomena are "prearranged in patterns that seem to be independent of my apprehension of them and that impose themselves upon the latter" (Berger, Luckmann, 1966, p. 35). Moreover, this reality is perceived by them as "an intersubjective world, a world that I share with others. This intersubjectivity sharply differentiates everyday life from other realities of which I am conscious" (ibid: 37 ). Another characteristic feature of the reality of everyday life is that it is "organized around the 'here' of my body and 'now' of my presence. This 'here and now' is the focus of my attention to the reality of everyday life" (ibid: 36). Therefore everyday life is always "someone's", or manifests itself through "something" (Sulima, 2003, p. 233), permeated with the present experience of "here and now" yet also leaning "forward" (ibid.).

According to P. Sztompka, "firstly, everyday life does not stand in opposition to festive time, it encompasses our entire experience; and, secondly, everyday life is not the opposite of an elitist life, as it encompasses the practices of all social classes. Thirdly, everyday life is not the same as private life, as opposed to public life. The category further includes such public events as: strikes, elections, political debates, along with private events: weddings, funerals, family feuds and Christmas dinners" (2008, p. 24). In his view, everyday life: Is always a life with others and in the presence of others; Is a series of recurring, or even cyclic, rhythmical or routine, events; Assumes dramatized, script-based forms of rituals; Engages physicality, biological equipment with all its limitations, weaknesses and frailties, but also with its potential, strengths and possibilities; Is located in space, takes place in particular places, which determines its content and character; Has a certain durability, shorter or longer time frameworks; Often has an unreflective, almost automatic nature; Is often characterized by spontaneity (ibid. 24-25).

The characteristic feature of everyday life is that it goes on continuously. Its quality and nature are determined by the space of everyday life, its time, social environment and material environment (cf. Tarkowska, 1994, 2009).

Conducting studies on everyday ordinary existence is important for a number of reasons. Showing what often goes unseen by people, and yet determines their fates, inspiring reflection and moral inspiration, can be used to shape a different present and future. The knowledge people have, their reflection on themselves (or lack thereof), the ability to see the whole context in which they live, links between their biography and history: all of these determine the nature of society (from the perspective of the studies presented here, especially concerning the nature of the teaching profession). Exploring the knowledge and conducting studies on 
everyday life - especially those construed in the qualitative paradigm, focused on an individual and personal experiences - allows for revealing and understanding previously unknown phenomena, placed beyond the major areas of studies, and addressing a significant number of diverse and complex occurrences. These include the ones related to one's workplace. Workplace has an impact on people staying, or "living", there. It provides various sensory experiences, allows for testing one's capabilities, and is a place where "a basic spatial organization of social life" takes place (Wentzel-Winther). From the perspective of analyses undertaken here, it is worth emphasizing that workplace is especially important for people in the context of building and reconstructing identity; as research suggests, place influences the shaping of the identity of a person spending time there (Mendel 2006, Lewicka, 2012, Relph, 1976).

To sum up, the main theoretical premises of the sociology of everyday life provide an inspiration to explore everyday life of teachers in the midlife transition period seeing, as Hartdwig stresses (1996, p. 27), the sociology of everyday life turns toward man, an individual, towards "ordinary people" and their "little experienced worlds". Therefore, the main focus has been placed on the ordinary everyday (professional) life of the teacher and its minute elements and manifestations.

\section{Midlife Transition Period}

A current stage of one's development has a significant impact on the perception of one's professional role and imposes meanings on it. For the purpose of this analysis, we will focus on the midlife transition period (Oleś, 2000). All stages of development are specific because of some dominant roles they play. For the midlife transition period these include: interpreting, making life meaningful, remembering achievements, accomplishments and failures, and reviewing one's life. Reaching middle age involves gaining a new perspective on life's tasks and problems. "Transition" implies an important qualitative change, a new outlook on life and the future, determined by past experiences and the awareness of life's finality.

The middle age period brackets vary. For the purpose of this analysis, we have assumed the age between 35 and 55 years as determining the time framework of the period (the nature of the midlife transition period is determined by a changing psychosocial situation of a person (Oleś, 2000). We can accentuate several common developmental tasks for people in this period (Brzezińska, 2004, p. 236): developing and cultivating relationship and bonds with one's life partner; cultivat- 
ing the development of family and housekeeping skills; generativity (productivity or creativity), i.e. taking responsibility for and engagement in the formation of a new generation, concern about the fate of a younger generation, taking care and meeting the needs of young people, helping growing children become happy and responsible people, the need to be useful in one's professional work and other areas of life and to create something that will serve others; establishing and sustaining a proper material standard of life; a constant effort in developing one's professional career, etc. (cf. Golka, 2009)

Among the problems of early middle age the most common are: changes within family, especially in relations with parents and children. "Also, the situation at work changes. There are new duties and functions, and if not, the confrontation of aspirations related to work and professional career with actual achievements becomes even more difficult" (ibid.). Furthermore, there is a threat of monotony and routine at work, or of the decrease in efficiency, which prompts one to ask the question: What should I change in my approach to work and which tasks are really important?

\section{Research Methodology}

The studies, with journal materials as the key subject of analysis, are conducted mainly within the framework of the humanities and social studies.

In current sciences, a biographical method is placed in the framework of qualitative methodology, with man - a conscious and autonomic study subject - as a starting point for empirical studies. In Poland, the first sociologist to employ biography as a material for scientific analyses was Florian Znaniecki. Including personal documents (letters, diaries, biographies) in sociological studies, Znaniecki introduced specific methodological principles in relation to them. One of them is the principle of the humanistic coefficient, according to which a sociologist must view social phenomena "through the eyes of their participants", and understand the meaning and motivations of human behaviors.

The mode of collecting research material, a journal competition, initiated by W.I. Thomas and F. Znaniecki (1976), marked the beginning of the dynamic development of sociological biography-based studies in Poland. A biography obtained through competition for a journal has also become a method of pedeutological studies. Bronisław Gołębiowski (1969) was the first to use a biography as a study method and a description as a source of knowledge in terms of pedeutology. He described a historical process of forming the teaching 
profession, starting with the persona of Kazimierz Deczyński - the first peasant parish teacher. His studies in the field of pedeutology are continued by Wanda Dróżka (2008), who analyzes the journals sent in as competition entries initiated by her in the context of their generation-based imagery and in the situation of change. The history and traditions of both sociology and pedeutology, in terms of the use of journals, provided inspiration also for the studies conducted by J. Łukasik (cf. Łukasik, 2011, 2013).

According to B. Smolińska Theiss and W. Theiss, biography is a basic method of qualitative research in pedagogy, presenting both a historically established position and a contemporary output (2010, pp. 84-85). Despite its clear-cut contours, the concept of biography is ambiguous and it "refers to a multifaceted and structuralized thematic area, in which the various internal relations and interconnections may give rise to confusion and controversy" (Lalak, 2010, p. 259). In order to avoid this and to specify the approach assumed in relation to the research presented in the article, the focus will be placed on a biography understood as a method and a tool.

A biography as a method. A biography is a narrative of one's life and activity. A biographical method in the broadest sense is an analysis of a course of the life of an individual, approached from a specific perspective: individual, social, professional, etc. (Helling: Leoński, 1993, p. 13). According to N.K. Denzin, "a biography presents experiences and definitions of a specific individual, group or organization in the way in which they are interpreted by this individual, group or organization" (Denzin, 1994, pp. 220-221). Accordingly, the studies of human behavior should be conducted from the perspective of the people they concern, and their objective is to reveal the history of experiences of a given person or group in their dynamic development (Kędzierska, 2012, p. 123).

A biography as a tool for studying social world. A biography understood as a life account is the vehicle for a certain content, usually in the form of a narrative. As a story, it has "its author, its subject, and a motif or an objective justifying the need to narrate. If it concerns the experiences of the narrator, it is an autonarrative" (Nowak-Dziemianowicz, 2012, p. 39). H. Kędzierska further specifies that in a biographical story, the narrative concerns oneself, one's own life story; it is a tool and component of self-recognition.

We might conclude that a biographical method, with a biography treated not only as a study subject, but also as a way of finding and gathering data and "subjecting them to humanistic analysis and an attempt to formulate theoretical generalizations, is for the representatives of social studies the most comprehensive form of biographical study" (Lalak, 2010, p. 265). 
An inspiration to address the subject of teachers' functioning in the home and school space has been drawn from the diaries of six teachers in their midlife transition period. The diaries, including the teachers' personal accounts of everyday life, were acquired through a competition. The presented article endeavors to address the following question: What professional experiences do the teachers in the midlife transition period describe in their diaries? The teachers under analysis were selected from among 47 competitors providing entries for a diary, journal or report competition entitled "A Month in the Life of a Teacher". The competition lasted from March to December 2009'.

The participants in the study are ordinary teachers with higher education: SENA - aged 41, married, two children attending high school and primary school respectively, works in a kindergarten, lives in the country, has marital problems caused by her husband's illness. MOTYLEK - aged 42, married, two children (college students), works in a kindergarten, the principal, lives in the country, has a happy marriage. SPEŁNIONA - aged 48, married, one child attending primary school, works in a kindergarten, the principal, lives in a small town, an unhappy marriage, separated. MAGOSIA - aged 50, married, one child (college student), teaches Polish in the secondary and high school complex, the school principal, lives in a city, has marital problems caused by her husband's illness. BIENIA - aged 52, married, three children, one child lives independently, one is a college student, one a high school student, teaches Polish in a vocational schools complex, lives in a city, has a happy marriage. SIŁACZKA - aged 52, married, three children, two are college students, one is a primary school pupil, teaches English in a primary school, lives in the country, experiences a marital crisis due to her husband's unemployment.

U. Flick believes that the sample selection for a qualitative study does not involve merely "selecting cases and materials, but also making choices within such cases and materials" (Flick, 2007, p. 67). In the presented study, the sample selection criteria included: sex (women), the stage of development (midlife transition), reflections, and the account of everyday life experiences spanning any given month (a full month, "day after day", working days and work-free days). A deliberately selected sample of participants in qualitative studies should be diversified, which

1 Initiated by Joanna Łukasik in 2009, the nationwide competition for a journal, diary or report entitled "A month in the Life of a Teacher" was designed to explore everyday life professional and non-professional experiences of teachers and their influence on their overall life, as well as meanings imposed on them. More details can be found in J. Łukasik's book (ed.) Z codzienności nauczyciela, Jastrzębia Góra: Black Unicorn 2011; J.M. Łukasik, Doświadczanie życia codziennego- narracje nauczycielek na przełomie życia, Kraków: Impuls 2013. 
best allows to "capture the variability and diversity of a studied phenomenon" (Flick, 2007, p. 59). Consequently, there were differences in terms of the number of children the women had, their life environment, their financial situation, their place of work, and the subject they taught. The category of difference concerned first and foremost their family situation, which is vital in experiencing everyday life after work. The similarities included: sex, professional stabilization, and the fact of being married.

The use of a biography as a method and research tool allows for addressing the issue posed in here, namely recognizing and describing which professional experiences are characteristic of female teachers in the midlife transition period. There is no previous analogical research in terms of methodological or theoretical assumptions in this area.

In analyzing the research data, references were made to the analysis of its content, i.e., "drawing conclusions based on systematically and objectively defined characteristics of communication" (O.R. Holsti, 1968, p. 601). In the systematic analysis of the content, "inclusion and exclusion of the content is conducted in accordance with specific selection criteria. This requirement eliminates the analyses which take into consideration only the data supporting the researcher's hypothesis" (O.R. Holsti, 1968, p. 598).

It is worth stressing that the studies of this kind, due to the adopted qualitative research orientation, do not entitle researchers to formulate conclusions or pose a thesis as to the existence of any tendency in the social dimension. The obtained picture of teachers' everyday lives is fragmentary and applicable mainly to the studied women, and any possible comparisons refer only to the analyzed cases and similarities or differences between them. The aim of the study is to recognize and describe in detail individual experiences, which may serve as a source of reflection as well as a basis for exploring and learning everyday life experiences in a broader context (including the quantitative research orientation).

\section{$\underline{\text { Research Results }}$}

An image of a person, perceiving "oneself" in a certain role, is formed through differentiating between what refers to oneself and what refers to the outside world. The image is determined by a number of factors. Among them we can distinguish: an external evaluation referring to oneself and an awareness of its adequacy; comparing oneself to others (a significant context of the reference group); and individual self-impressions. A real image of oneself allows one to fulfill aspirations 
and shape one's workplace in a way that allows others in their environment to develop fully.

An adult tends to devote more time to work than any other activity. Therefore, it is hardly surprising that the teachers' everyday reality presented in the journals is full of experiences related to professional work, even after finishing it. This would support a thesis that it is difficult to set a boundary between the private and professional spheres in teachers' lives as work engages their whole personality (ibid.). In the majority of professions, it is possible to differentiate between the private and professional spheres, and, consequently, the functioning within the two life circles, while often coinciding, is mostly independent (Sośnicki, 1968, p. 59).

Writing about themselves through the prism of their work, the teachers emphasize that:

Professional work is an integral part of their private, non-professional life. They note that it is impossible to leave what happens in school or pre-school behind, and focus exclusively on what is about to take place at home, while shopping or socializing.

Teachers think of their professional activities both at and after work as highly important. For them work is a source of satisfaction, a place where they can achieve success, pursue professional goals, gain a sense of achievement and be important for their students, while also being a source of financial income. They find their work meaningful, feel needed by their students, and therefore engage in various after-work activities to meet their students' needs or to fulfill tasks resulting from their professional roles.

Work is especially important for women in the midlife transition period as their goal is to leave behind material and intangible traces, imprinted on their students' memory. They believe that the teacher's mission is to leave behind a lasting mark in others' memory.

Engagement in professional work manifests itself also in writing articles on students' educational achievements, stories for children or lesson plans, and in sharing their knowledge with other teachers and publishing in teachers' journals.

For the subjects work is a true vocation and everyday challenge. It gives them a sense of fulfillment and satisfaction. Thanks to contacts with children/youth they feel young and full of energy, and good relations with students allow them to teach and stay effective. (BIENIA writes: My profession certainly makes me stay young. And this is another beautiful thing about it. Being in everyday contact with young people makes one feel young. Students do not allow one to grow old. Thanks to them I got to know hip-hop and even became the manager of an amateur band. 
Sometimes they force me to think in their categories and I feel that because of that I can understand them better.)

The analyzed teachers have complex, established professional goals and are determined to meet them.

They consider activities undertaken at and outside of work as highly important. For them work is a source of satisfaction, a place where they can achieve success, pursue professional goals, gain a sense of achievement and be important for their students, while also being a source of financial income. They find their work meaningful, feel needed by their students, and therefore engage in various after-work activities to meet their students' needs. (SENA writes: The Principal was not surprised at all. She knows that even during the summer holiday my heart is in school.)

Experiences related to relationships with people from work, work-related problems and issues, along with joys, cause the subjects to go over their workday after getting home, ordering experiences and pondering over them.

They share their work experiences with husbands, or with children or friends, if their relations with husbands are not good.

Women undergoing a crisis in their marriage, lacking a good relationship with their husbands and not fulfilled as wives compensate through their professional work, through their engagement in tasks resulting from professional roles and/or functions.

Work-free time is not the same as leisure time for the subjects, as it is dominated by duties related to the teaching profession, or typical housework and domestic duties. Days off and Sunday evenings are used for preparing Monday classes, and summer holiday and mid-term breaks are also filled with work-related tasks, e.g. writing projects and lesson plans, furnishing classrooms and laboratories, etc.

Professional work and activity of women in the midlife transition period helps create and reinforce identity, and the discussed professional experiences act, to a considerable degree, as their component (cf. Prokop, Łukasik, 2012). They provide for the women the basis for building family relations and act as an element allowing for self-identification and the construction of one's self-esteem.

\section{Conclusion}

Reflections on everyday life experiences reveal the extent to which the analyzed teachers perceive themselves through the prism of their professional roles (cf. Piorunek, 2009). Thanks to that activity, the teachers are not subject to the 
minimalism of desires, reduction of effort, regress and marginalization. From the accounts of their everyday lives we can see how, as a result of new challenges, experiences, situations, emerging crises and difficulties (which are often part of the factors characteristic of the midlife transition period), as well as their successes, they become more mature and complex (King et al., 2007, p. 38). Their everyday life (both professional and non-professional), experiences (past and present) and analyses of their lives in the midlife transition period lead to breaking schematic rules of life according to a single, required and desired pattern. Furthermore, their responsibility for work, comprehension of its meaning and purpose, and identification with the unique mission of the teaching profession give their work special meaning. At this stage of their lives, the women have considerably more time for work (with their own children already self-sufficient) and more experience in terms of their profession. Accordingly, they may devote it to work, education and students, also wishing to stay imprinted in their memory. For teachers, their professional and private worlds are inextricably intertwined and permeate one another. In the course of their professional career, the scope and intensity of their mutual interrelations do not subside. On the contrary, in breakthrough moments and during personal crises they increase in importance. Reflections on everyday non-professional life of teachers allow for going beyond the existing models of viewing their lives, and comprehending the consequences of the complexity of professional and non-professional life that manifests itself in the lack of boundaries between them. Furthermore, an insight into everyday experiences of the teachers in breakthrough moments is crucial in terms of the studies on their professional and life situations and, accordingly, in terms of engaging in the activities reinforcing specific areas of their life and functioning.

\section{References}

Berger, P.L., Luckmann T. (1966). The Social Construction of Reality: A Treatise in the Sociology of Knowledge. New York: Anchor Books.

Brzezińska, A. (2004). Społeczna psychologia rozwoju. Warszawa: SCHOLAR.

Denzin, N.K., Lincoln Y.S. (1994). Handbook of Qualitative Research. London: Sage.

Dróżka, W. (2008). Generacja wielkiej zmiany: studium autobiografii średniego pokolenia nauczycieli polskich 2004. Kielce: Wyd. Akademii Świętokrzyskiej.

Flick, U. (2007). Designing Qualitative Research. London: Sage.

Fontana, A. (2005). Sociologies of everyday life. In: Ritzer, G. (red.) Encyclopedia of Social Theory. vol. 2. Thousand Oaks. California: Sage, 774-776.

Gołębiowski, B. (1969). Szkoła i wychowanie w zmiennym społeczeństwie (w świetle 
pamiętników i innych badań). In: Młode pokolenie wsi Polski Ludowej, T. 6, Nauczyciele i uczniowie. Pamiętniki. Warszawa: LSW.

Golka, M. (2009). Czy jeszcze istnieje nie-codzienność? In: Bogunia-Borowska, M. (red.) Barwy codzienności. Analiza socjologiczna. Warszawa: SCHOLAR, pp. 65-76.

Hartdwig, W. (1996). Historia codzienności dzisiaj. Bilans krytyczny. In: Schulze, W. i in. Historia społeczna. Historia codzienności. Mikrohistoria. Warszawa: Wolumen, Niemiecki Instytut Historyczny.

Holsti, O.R. (1968). Content analysis. In: Lindzey, G., Aronson, E. (red.), The handbook of social psychology. Reading, MA: Addison-Wesley, (2 ${ }^{\text {nd }}$ ed., pp. 596-692).

Kędzierska, H. (2012). Kariery zawodowe nauczycieli. Konteksty - Wzory - Pola dyskursu. Toruń: Wydawnictwo Adam Marszałek.

King, L.A., Wells, J.E., Burton, Ch.M (2007). Pojęcie dobrego życia - w ujęciu szerokim i wąskim. In: Lindley, P.A., Joseph, S. Psychologia pozytywna w praktyce. Warszawa: PWN.

Lalak, D. (2010). Życie jako biografia. Warszawa: Wydawnictwo Akademickie „Żak”.

Leoński, J. (1993). Różne sposoby ujmowania metody biograficznej w socjologii. In: Rzepa, T.,.Leoński, J. (red.). O biografii i metodzie biograficznej, Poznań: Wydawnictwo Nakom. Lewicka, M. (2012). Psychologia miejsca. Warszawa: SCHOLAR.

Łukasik, J. (ed.) (2011). Z codzienności nauczyciela. Jastrzębia Góra: Black Unicorn.

Łukasik, J. (2013). Doświadczanie życia codziennego-narracje nauczycielek na przełomie życia. Kraków: Impuls.

Mendel, M. (red.) (2006). Pedagogika miejsca, Wrocław: Wydawnictwo DSWE TWP.

Nowak-Dziemianowicz, M. (2012). Edukacja $i$ wychowanie $w$ dyskursie nauki i codzienności. Kraków: Impuls.

Oleś, P. (2000). Psychologia przełomu połowy życia. Lublin: Towarzystwo Naukowe KUL. Piorunek, M. (2009) Bieg życia zawodowego człowieka. Kontekst transformacji kulturowych. Poznań: Wydawnictwo Naukowe UAM.

Prokop, J., Łukasik, J. (2013). 1.3.Trendy ve vzdělávaní polských učitelů. In: Kohnová, J. a kol. Profesní rozvoj učitelu a cíle školního vzdělávání. Praha: Univerzita Karlova v Praze, 49-60.

Relph, E. (1976). Place and placelessness. London: Pion.

Sośnicki, K. (1968). Poradnik dydaktyczny. Warszawa: PZWS.

Schütz, A. (1962). On Multiple Realities. Hague: Martinus Nijhoff.

Sulima, R. (red.) (2003). Życie codzienne Polaków na przełomie XX i XXI w. Łomża: Oficyna Wydawnicza „Stopka”.

Sztompka, P.(2008). Życie codzienne - temat najnowszej socjologii. In: Sztompka, P., Bogunia-Borowska, M. (ed.). Socjologia codzienności. Kraków: Znak, 15-52.

Smolińska-Theiss, B, Theiss, W. (2010). Badania jakościowe - przewodnik po labiryncie. In: Palka, S. (ed.) Podstawy metodologii badań w pedagogice. Gdańsk: GWP, 79-102

Thomas, W.I., Znaniecki, F. (1976). Chłop polski w Europie i Ameryce. t. 3. Warszawa: LSW. Tarkowska, E. (1994). Życie codzienne w domach pomocy społecznej. Warszawa: IFiS PAN. 